\title{
比喻研究のための直喻刺激-解釈セット作成 および妥当性の検討
}

\section{岡 隆之介 京都大学 大島 裕明 兵庫県立大学 楠見 孝 京都大学}

\section{Development and validation of an item set of simile interpretations for metaphor research}

\author{
Ryunosuke Oka (Kyoto University), Hiroaki Ohshima (University of Hyogo), \\ and Takashi Kusumi (Kyoto University)
}

\begin{abstract}
The purpose of this study was to develop and test the validity of an item set of simile interpretations for metaphor research. We conducted three tasks. In an interpretation generation task, 50 university students generated up to three interpretations for each of 120 simile expressions collected by Nakamoto and Kusumi (2004). In a conventionality rating task, 24 university students rated the conventionality of vehicles based on the most typical interpretation collected in the interpretation generation task. In a metaphor preference rating task, 24 university students rated their metaphor form preference. Our results showed significant positive correlations between topicvehicle similarity ratings collected in a previous study and the number of interpretations. In addition, linear regression analysis of the metaphor preference rating showed significant positive effects of vehicle conventionality, topic-vehicle similarity, and entropy. These results solidly replicated the results reported in previous studies and confirmed the validity of an item set of simile interpretations. The usefulness of simile interpretations collected in this study for future metaphor studies is discussed.
\end{abstract}

Key words: metaphor, simile, interpretation, topic-vehicle similarity, preference for metaphor.

The Japanese Journal of Psychology

2019, Vol. 90, No. 1, pp. 53-62

J-STAGE Advanced published date: December 25, 2018, https://doi.org/10.4992/jjpsy.90.17236

「笑顔は花のようだ」のように，比喻は主題（笑顔） を喻辞 (花)でたとえて伝える言語表現である。特に, 主題と喻辞の比喻関係が明示された表現（笑顔は花の ようだ）を直喻と呼び, 主題と喻辞の比喻関係が明示 されていない表現（笑顔は花だ）を隠喻と呼ぶ。本研 究では, 比喻と呼ぶ場合には直喻と隠喻を区別しない で扱う。

心理学における比喻の研究は, 比喻の理解過程 (Bowdle \& Gentner, 2005; Kintsch, 2000) や産出過程 (Chiappe \& Chiappe, 2007)について明らかにしてきた。

Correspondence concerning this article should be sent to: Ryunosuke Oka, Division of Cognitive Psychology in Education, Graduate School of Education, Kyoto University, Yoshida-Honmachi, Sakyo-ku, Kyoto 606-8501, Japan. (E-mail: Qualia1006@gmail.com)

本研究の一部は京都大学大学院デザイン学連携プログラム による研究助成, JSPS 科学研究費助成事業 JP16H02906による 助成を受けた。研究結果の一部は日本認知科学会第 34 回大会に おいて発表された。
特に近年の比喻研究においては, 比喻とその解釈の関 係を明らかにすることや，そうした関係が明らかな刺 激セットを利用する研究が増えてきた。たとえば比喻 の理解研究においては, ある比喻に対して人がどのよ うな解釈を産出するかを明らかにした研究 (Kintsch, 2000; 平・中本・楠見, 2007）がある。また, 比喻の 産出研究においては, 主題と, その主題と関連のある 解釈を特徵として提示することで比喻を産出させる課 題 (Beaty \& Silvia, 2013; Chiappe \& Chiappe, 2007; Utsumi \& Sakamoto, 2014）を用いることがある。こう した比喻の産出研究を行う上では, 比喻と対応する解 釈が明らかになっている刺激セットによって，より厳 密な統制ができる。たとえば，参加者に呈示する主題 (例：笑顔）と関連する特徵（例：明るい, あるいは 華やか) を柔軟に変更することで，特徴を説明する際 に用いる喻辞（例：花，あるいは光）がどのように変 化するかを検討するなどの新たな研究が可能になる。 また, 比喻の理解研究においては, その比喻の持つ心 
理的変数（例：その比喻がどれくらい面白いか）と解 釈の内容や量の関係を明らかにすることができる(平. 楠見・内海，2012）。これらのことを踏まえると，比 喻とその解釈の関係が明らかになっている刺激セット を提供することは, 比喻の理解や産出研究を厳密な材 料統制に基づいて展開する上で，重要であると考えら れる。しかしながら, 現在のところ比喻とその解釈に ついて整理された刺激セットは存在していない。

本研究では, 比喻とその解釈を収集し, 比喻研究の ための刺激セットを作成し，その妥当性を検討するこ とを目的とする。具体的には，参加者に中本・楠見 （2004）で収集された直喻を提示し解釈を産出させる。 さらに, 直喻の解釈の中でももっとも回答数の多かっ た回答（以下，第一解釈とする）を対象に測定する喻 辞の慣習性（その喻辞の最も典型的な比喻的意味を指 して使われることが慣用的である程度）と，隠喻に対 する選好性（比喻の形式として直喻よりも隠喻が好ま れる程度）に関わる評定を求める。そして, 中本・楠 見 (2004) で収集された心理的変数と，本研究で新た に収集した心理的変数を用いて，本研究で得られた データが先行研究の結果 (Katz, Paivio, Marschark, \& Clark, 1988; 平 · 中本 - 楠見, 2006）や理論（Bowdle \& Gentner, 2005; Chiappe \& Kennedy, 2001; Utsumi, 2007）と照らして妥当であるかを検討する。

本研究で用いる比喻は中本・楠見 (2004) で報告さ れた 120 個の「A（名詞）はB（名詞）のようだ」と いう形式の直喻である。中本・楠見（2004）で報告さ れた直喻を用いる理由は 2 つる。1つ目は, 120 個 の直喻は, 比喻に関する心理学的研究（楠見, 1995; Nakamoto, 2003; Ortony, Vondruska, Foss, \& Jones, 1985) や，比喻表現辞典（榛谷，1994; 中村, 1994）加網羅 的に収集された比喻表現であり，心理学的研究に適し た刺激だと考えられるためである。2つ目は，120 個 の直喻は，心理的印象評定が報告されている数少ない 日本語の直喻の項目リストであるためである。120 個 の直喻は，（a）その直喻が言い表そうとしている意味 をどの程度明確に理解できるか（理解可能性），（b) 主題と喻辞がどの程度意味的に似ているか（構成語類 似性)，(c) その直喻がどの程度見聞きしたことのな いオリジナリティのある文か (独創性)，そして (d) その直喻の意味内容に面白さや意外性が感じられるか (面白さ) に関する，248名の参加者からそれぞれ 9 件法で評価された心理的印象評定值を持っている。先 行研究で得られた心理的印象評定值に, 本研究で得ら れる直喻に対する解釈のデー夕を加えることができれ ば, 今後の比喻研究において有用な刺激セットを提供 できると考えた。

本研究で得られた刺激セットが妥当であるかを検討 するために, 4 つの予測を検討する。

1 つ目の予測は, 直喻に対する解釈数と中本・楠見
（2004）で報告された構成語類似性が正の相関関係を 示すというものである。Katz et al.（1988）は，240 個 の詩的な隠喻と 260 個の詩的でない隠喻を 634 名の参 加者に提示し, 隠喻から想起される解釈の数の自己報 告と, 構成語類似性を含む 10 個の特性の評定を求め た。その結果，隱喻から想起される解釈の数は構成語 類似性と.61-.62 の中程度以上の正相関を示した。 また, 平他 (2006) は30 個の直喻について, 構成語 類似性と直喻に対する解釈の数が .38 の中程度の正相 関にあることを報告した。

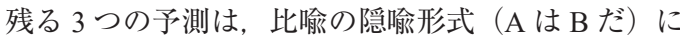
対する選好性を，どのような変数が予測するかに関す る理論から導かれた。比喻の理解過程においては, 喻 辞のカテゴリ化と, 主題と喻辞の比較のそれぞれの処 理過程が重要であると言われている（Bowdle \& Gentner, 2005)。そして, ある比喻の理解過程において, 喻辞のカテゴリ化が重視される比喻（例 : 笑顔は花だ） は隠喻形式が好まれる一方で，主題と喻辞の比較が重 視される比喻（例：美は虫歯のようだ）は直喻形式が 好まれることが知られている（Bowdle \& Gentner, 2005; Utsumi, 2007)。本研究では, 隠喻形式に対する選好性 を予測する変数が何であるのかに関わる 3 つの理論 (Bowdle \& Gentner, 2005; Chiappe \& Kennedy, 2001; Utsumi, 2007）を踏まえて, 刺激セットの妥当性を検 討する。

2つ目の予測は，喻辞の慣習性が隠喻に対する選好 性を正に予測するというものである。Bowdle \& Gentner（2005）の隠喻履歴仮説（career of metaphor hypothesis）は，喻辞の最も典型的な比喻的意味を指 して使われることが慣用的である程度を喻辞の慣習性 とよび，これが高い比喻（例：笑顔は花だ）における 喻辞はすでに主題と十分に比喻的意味（どちらも明る い）で関連づけられているため，喻辞の字義的意味と の比較を文法的に促されている直喻でなく，主題が喻 辞のカテゴリ的成員であることが文法的に促されてい る隠喻で十分に理解可能であるという。一方で, 喻辞 の慣習性が低い比喻（例：休日は道しるべだ）におけ る喻辞は主題との十分な比喻的意味の関連づけがなさ れていないため, 喻辞の字義的意味との比較が必要に なり, その結果として直喻の方が隠喻よりも理解が容 易であるという。この予測を裏付けるように, Bowdle \& Gentner（2005, Study 1）では喻辞の慣習性が低い時 に, 直喻（例：結婚は冷蔵庫のようだ）は隠喻（例： 結婚は冷蔵庫だ）よりも好まれることを示している。 一方で, 喻辞の慣習性が高い時には，隠喻が直喻より も好まれることを示している。

3つ目の予測は, 参加者の直喻に対する解釈から算 出されるエントロピーが隠喻に対する選好性を正に予 測するというものである。Utsumi（2007）の解釈多様 性理論（interpretive diversity theory）は，喻辞が主題 
に関連した様々な特徵を一様な分布で保持している （すなわち，解釈のエントロピーが高い）場合には, その比喻の主題は喻辞の良いカテゴリと言えるため に，隠喻が好まれると説明している。この予測を検討 するために, Utsumi（2007）は調査法によって, 構成 語類似性，喻辞の慣習性に加えて，比喻に対して参加 者が産出した解釈から求められるエントロピー（解釈 の多様さを表す指標), 比喻の適切性，そして比喻の 親しみやすさが，隠喻に対する選好性を予測するかを 相関分析と重回帰分析によって検討した。その結果, 相関分析においてはすべての説明変数が隠喻形式に対 する選好性と正の相関関係を持ったが，重回帰分析に おいては喻辞の慣習性とエントロピーだけが隠喻に対 する選好性を正に予測したことを示している。

4つ目の予測は, 構成語類似性が隠喻に対する選好 性を正に予測するというものである。Chiappe \& Kennedy（2001）の比喻的言語の字義基盤理論（literal base theory of figurative language) は, 隠喻はカテゴリ 宣言文であるために主題と喻辞が多くの特徵を共有し ている（すなわち, 構成語が類似している）必要があ る一方で, 直喻は比較を促す文であるために主題が喻 辞の特徵のいくつかを共有していれば良い(すなわち， 構成語が類似している必要はない) と考える。この予 測と一致するように，Chiappe \& Kennedy (2001, Exp 1, Exp 2) では，構成語の類似性の評定值と隠喻に対す 選好性の評定值の間に正の相関関係（それぞれ $r \mathrm{~s}=$ .61, .75) がみられている。

これまでの予測をまとめ直すと以下の通りである。 相関分析に抢いて, 中本・楠見 (2004) の構成語類似 性と個人が産出する解釈数は正の相関を示す（予測 1)。また，隠喻に対する選好性の評定值を目的変数と する重回帰分析において, 喻辞の慣習性の評定值, 参 加者の直喻に対する解釈から算出されるエントロ ピー, そして構成語類似性は正に影響を持つ（予測 2, 3, 4)。これらの予測の中でも, 喻辞の慣習性と解釈 のエントロピーが隠喻に対する選好性を予測するかど うかを検討することは, 比喻の解釈を収集することで 初めて実証検討可能な問題であるため, 刺激セットの 有効性を確認する上でも有用である。

\section{方法}

本研究では解釈産出課題, 表現の選好性課題, そし て喻辞の慣習性課題の 3 つの課題を行う。解釈産出課 題では, 直喻から産出される個人の解釈数と, 直喻の 代表的な解釈を収集する。表現の選好性課題では, 隠 喻に対する選好性の評定值を収集する。喻辞の慣習性 課題では, 解釈産出課題で得られたもっとも多かった 回答（第一解釈）を用いて, 喻辞の慣習性の評定値を 収集する。

実験参加者 解釈産出課題には大学生 50 名（男性
24 名, 女性 26 名）が参加した。参加者の平均年齢は 21.5 歳で, 標準偏差は 2.3 歳であった。参加者の所属 学部・研究科の内訳は, 理系 (農学, 工学, 薬学, 理 学, 医学) が 28 名, 文系 (法学, 経済学, 文学, 教 育学) が 20 名, 総合系が 2 名であった。本研究と同 様に，比喻に対する解釈を記述させた平・楠見 (2005) やUtsumi (2005) は, 合計の参加者数は多いものの（そ れぞれ 174 名と 80 名), 回答は比喻ごとに按分されて おり，それぞれの比喻に割り当てられた参加者数はど ちらの研究も $20-35$ 名程度であった。そのため, 本 研究では 50 名が全ての直喻に回答することを踏まえ ると, 本研究の参加者数は同等以上と判断した。

表現の選好性課題と喻辞の慣習性課題には大学生 24 名（男性 11 名, 女性 13 名）が参加した。参加者 の平均年齢は 20.9 歳で, 標準偏差は 1.9 歳であった。 参加者の所属学部・研究科の内訳は, 理系が 15 名, 文系が 6 名, 総合系が 3 名であった。本研究と同様に

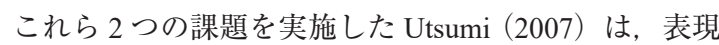
の選好性課題に 30 名, 喻辞の慣習性課題に 18 名を割 り当てて, 隠喻に対する選好性と喻辞の慣習性の相関

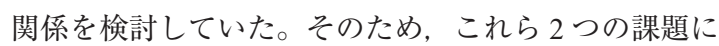
対する本研究の参加者数は, Utsumi (2007) と比べて 同程度と判断した。

実験刺激 解釈産出課題は, 中本・楠見 (2004) で 作成された 120 個の直喻を用いた。先行研究の 120 個 の直喻は, 構成語類似性の平均評定值の範囲が 9 点尺 度で $1.4-7.7$ と十分な幅を持っていた。また，表現 の選好性課題と喻辞の慣習性課題は, 中本・楠見 （2004）で作成された 120 個の直喻に加えて, 喻辞の 慣習性課題で得られた第一解釈を用いた。

解釈産出課題 実験はコンピュー夕上で行われた。 この課題で, 参加者は画面中央に提示される直喻を読 み, その解釈を回答闌に最低 1 つ, 最大 3 つまでキー ボードで入力することが求められた。参加者の解釈数 の回答上限を 3 つにしたのは以下に述べる 2 つの理由 からである。1つ目の理由は, Katz et al. (1988) の調 查結果に基づいている。この研究で報告された参加者 の隠喻に対する解釈の数の自己報告の平均回答数は 1.59 - 1.68 であり, 標準偏差が $0.33-0.34$ であった。 そのため, 標準偏差を考慮しても参加者が隠喻に対し て思いつく解釈数は 3 を下回ると考えたためである。 2 つ目の理由は, 平・楠見 (2005) の研究の調查結果 に基づいている。この研究では, 参加者に直喻を提示 し, その表現に対して思いつく解釈を最大 10 個まで 回答させた。その結果, 参加者の直喻に対する解釈の 平均産出数は 1.29 - 2.56 であった。これらの結果から, 解釈の上限は 3 が良いと考えた。参加者には回答に際 して，(a）解釈が3つ書けたら次へ進んでかまわない こと, (b) 1 分間は解釈が2つ書けるまで回答をやめ ないこと，(c) それぞれの解釈が他の解釈の言い換え 
にならないように努めること，そして（d）1 分間が 経過した時点で $2 つ$ 目の解釈が思い浮かばなかったら 次へ進んでかまわないことを教示した。また，実験画 面の左上には，直喻の提示を開始してから 1 分間が経 つまでの残りの秒数が呈示されていた。残りの秒数が 0 秒になると同時に「1 分間が経ちました。現在の回 答が終わったら次へ進むを押してください」という メッセージが画面上に現れ，参加者に次へ進むことを 促した2。

参加者は「次へ進む」というボタンを押すと，休息 画面に入った。参加者は休㮩画面で適宜休鄎を挟むよ う説明を受けた。休悡画面で「次へ進む」を押すと次 の直喻の解釈を産出することが求められた。

表現の選好性課題 Bowdle \& Gentner (2005) やUtsumi （2007）にならい，直喻（例：笑顔は花のようだ）とそ れを隠喻に改めたもの（笑顔は花だ）を左右に同時に呈 示し, どちらの表現を選好するかを 9 件法で尋ねた。直 喻と隠喻の呈示位置は参加者ごとにカウンターバラン スをとった。評定結果は值が大きくなるほど隠喻の選好 が高くなるよう（1：直喻がよいー $5:$ どちらとも言え ないー9：㩊喻がよい）に変換した。

喻辞の慣習性課題 Bowdle \& Gentner (2005) や Utsumi （2007）を参考に, 直喻（例：笑顔は花のようだ）の喻 辞（花）と第一解釈（美しい）を上下に同時に提示し, 喻辞を用いて第一解釈に言及することがどれくらい慣 習的であるかを 9 件法 (1：非常に新しい一 5 ：どちら ともいえない一9：非常に慣習的）で尋ねた。

手続き 解釈産出課題では 1 名から 6 名の参加者が 同時に参加した。実験は小集団実験室で行われ，この 実験室において参加者は 1 人に 1 台コンピュータが割 り当てられていた。また, 実験室内は参加者がお互い を見えないようにパーティションによって区切られて いた。はじめに，解釈産出課題の説明を行った。説明 の後に, 実験では使用していない 4 つの直喻を用いて 解釈産出課題の練習試行を行った。練習試行が終わっ たのち，本試行を行った。実験時間はおよそ 2 時間半 であった。

表現の選好性課題と喻辞の慣習性課題では, 参加者 は個別に実験室で実験に参加した。はじめに, 実験室 に訪れた参加者に対して実験の概要を説明した。続い て, 表現の選好性課題の説明を行った。説明の後に, 実験では使用していない 4 つの直喻と隠喻の対を用い て表現の選好性課題の練習試行を行った。練習試行が 終わったのち, 本試行を行った。表現の選好性課題が 終わったのち, 同様の手順で喻辞の慣習性課題を行っ た。実験時間はおよそ1時間であった。

1 分間で参加者に回答終了を促すようにしたのは，参加者の 実験に対する負荷を軽隇するためであった。なお，この教示が 終わった後でも参加者は回答を継続できるようになっていた。

\section{結果と考察}

はじめに解釈産出課題における結果を整理する。続 いて, 中本・楠見 (2004) で得られた結果と本研究の 結果を用いて, 直喻の特性と解釈関連指標間の相関分 析および，隠喻に対する選好性を予測変数とする重回 鲕分析を行うことで, 本研究で得られたデータが刺激 セットとして妥当であるかを検討する。

解釈産出課題における参加者の回答の整理 解釈産 出課題で得られた回答をまとめるため, 本研究では平. 楠見（2005）やUtsumi（2005）を参考に，(a) 個人が 産出した解釈数, (b) 解釈タイプ数, (c) 解釈トーク ン数, そして（d）解釈のエントロピーを求めた。(a) 個人が産出した解釈数は, 解釈産出課題における参加 者の直喻に対する回答数（最低 1 つ, 最大 3 つ）の平 均值を用いた。

(b) 解釈タイプ数と (c) 解釈トークン数は, Utsumi (2005) を参考に, 参加者の課題における全回 答を第 1 著者が分類して求めた。この分類は以下に 述べる4つの手続きをとった。第 1 の手続きとして, 明らかに解釈ではない回答（主観的な体験について 述べた回答，あるいは回答として成立していない回 答）は除外した（例：「誰か助けてえー」 $\rightarrow \mathrm{NA}$ ）。第 2 の手続きとして, 直喻ごとに回答の意味内容が類似 する回答を同一のトークンとみなす前処理を行った。 この前処理では, (a) 辞書形が同じ回答（例：「かわ

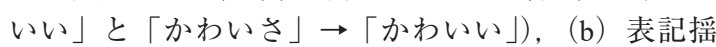

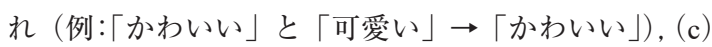
副詞による修飾の有無（例：「熱い」と「とても熱い」 $\rightarrow\lceil$ 熱い」), (d）格助詞（てにをは）・係助詞（も）・ 助動詞（べき）による違い（例：「乗り越えるもの」 と「乗り越えるべきもの」 $\rightarrow$ 「乗り越えるもの」), (e) 明らかな誤字 (例:「純粋無垢である」と「純真無垢だ」 、「純真無垢だ」)，(f) 回答の中心的な役割を担う 単語やフレーズが一緒（例：「見る者を幸せにする」 と「見た人を幸せな気分にする」と「人を幸せにする」 「「人を幸せにする」), そして $(\mathrm{g})$ 外来語（主に英語） を日本語に置き換えた時に，単語の意味が同じにな る表現（例：「自分で制御できない」と「自分でコン トロールできない」 $\rightarrow$ 自分で制御できない」）といっ た事項を考慮した。第 3 の手続きとして, 上記の手 続きの後に，2つ以上の同一トークンが得られなかっ た回答を以後の分析から除外した。第 4 の手続きと して, 得られたトークンを国語辞典『スーパー大辞林』 で調べ，あるトークンの説明の中に別のトークンが 含まれている場合, その 2 つのークンを同一トー クンとした（例：「きれい」という語は「目に見て美 しく心地よいさま」という説明がされているため,「美 しい」と同一のトークンとみなした)。第 4 の手続き を終えた時点で求めた，それぞれの直喻のトークン 
Table 1

直喻に対する解釈指標の值と出現頻度の上位三解釈

\begin{tabular}{|c|c|c|c|c|c|c|}
\hline ID & 直喻 & 解釈数 & エントロピー & $\begin{array}{l}\text { 隠喻に対 } \\
\text { する選好 }\end{array}$ & $\begin{array}{l}\text { 喻辞の } \\
\text { 慣習性 }\end{array}$ & 第一, 第二, 第三解釈 \\
\hline 71 & 気配 - 足音 & 3.00 & 3.21 & 3.54 & 7.04 & 近づいてくる, 微かだ, 忍び寄る \\
\hline 39 & 研究 - 登山 & 2.86 & 3.63 & 5.50 & 7.04 & 達成感がある, 険しい道のり, 苦しい \\
\hline 68 & 道 - 血管 & 2.84 & 4.03 & 2.88 & 4.33 & 繋がっている, 分かれている, 複雑だ \\
\hline 57 & 毛髪 - 絹糸 & 2.84 & 3.33 & 2.33 & 6.79 & 細い, 美しい, 柔らかい \\
\hline 9 & 子供 - 天使 & 2.84 & 3.01 & 6.96 & 7.54 & かわいい, 無垢た, 癒される \\
\hline 118 & 部屋 - 海底 & 2.84 & 2.98 & 2.54 & 7.38 & 暗い, 静かだ, 広い \\
\hline 5 & 激怒 - 噴火 & 2.82 & 3.39 & 3.33 & 8.17 & 勢いが激しい, 突然起こる, 止まらない \\
\hline 26 & 真珠 - 水滴 & 2.82 & 2.74 & 1.83 & 5.67 & 美しい, 丸い, 透き通っている \\
\hline 7 & 男 - 狼 & 2.80 & 4.34 & 6.92 & 7.29 & 怖い, 強い, 一人で行動する \\
\hline 44 & 革命 - 地震 & 2.80 & 3.40 & 4.17 & 7.13 & $\begin{array}{l}\text { 突然起こる, 人に影響を与える, いつ起こるかわ } \\
\text { からない }\end{array}$ \\
\hline 24 & 粉雪 - 羽毛 & 2.80 & 2.49 & 2.04 & 8.21 & 柔らかい, 白い, 軽い \\
\hline 35 & 太股 - 大根 & 2.80 & 2.42 & 2.58 & 7.63 & 太い, 白い, 毛が生えている \\
\hline 14 & 暴動 - 嵐 & 2.78 & 3.24 & 4.54 & 8.38 & 激しい, 巻き込む, 突然起こる \\
\hline 3 & 人生 - 航海 & 2.76 & 3.62 & 8.08 & 8.00 & 長い, 危険がある, 困難がある \\
\hline 60 & 心 - 沼 & 2.76 & 3.51 & 4.17 & 8.00 & 深い, 暗い, 抜け出せない \\
\hline 74 & 子猫 - 王女 & 2.76 & 2.94 & 3.63 & 5.63 & かわいい, 大切にされている, わがままだ \\
\hline 70 & マグロ - 砲弾 & 2.74 & 3.19 & 2.50 & 6.08 & 速い, 黒い, 泳ぐ \\
\hline 4 & つらら - 水晶細工 & 2.74 & 3.04 & 3.96 & 7.58 & 美しい, 透明だ, 纎細だ \\
\hline 23 & 感情 - 渦 & 2.72 & 3.67 & 4.67 & 7.33 & 巻き込まれる, 抜け出せない, 色々なものが混ざる \\
\hline 52 & 仕事 - 牢獄 & 2.72 & 3.45 & 5.75 & 7.25 & 辛い, 逃れられない, 閉じ込められる \\
\hline 96 & 柿ーちょうちん & 2.72 & 3.24 & 2.21 & 6.88 & 赤い, ぶら下がっている, 丸い \\
\hline 2 & 笑顔 - 花 & 2.72 & 3.16 & 4.50 & 8.33 & 美しい, 明るい, 華やかである \\
\hline 38 & 蝶 - 踊り子 & 2.70 & 3.52 & 3.58 & 8.42 & 舞う, 美しい, 華やかだ \\
\hline 22 & 議論 - 戦争 & 2.70 & 3.12 & 6.67 & 7.67 & 激しい, 対立する, 勝ち負けを決める \\
\hline 6 & 大地 - 母親 & 2.66 & 3.91 & 5.75 & 4.83 & 大きい, 包み込む, 暖かい \\
\hline 77 & 山 - 王様 & 2.66 & 3.81 & 4.50 & 4.96 & 大きい, 動かない, 威厳がある \\
\hline 55 & 理論 - 建物 & 2.66 & 3.38 & 4.17 & 5.46 & 組み立てる, 積み重ねる, 崩れる \\
\hline 54 & 情熱 - 溶岩 & 2.66 & 3.04 & 4.67 & 7.96 & 熱い, あふれでる, 冷めやすい \\
\hline 72 & 香水 - 花束 & 2.66 & 2.85 & 3.25 & 6.71 & 良い香りがする, 華やかだ, 様々な香りがする \\
\hline 119 & 麦畑 - 海 & 2.66 & 2.40 & 3.38 & 8.58 & 広い, 波打つ, 風になびく \\
\hline 94 & 吹雪 - 濁流 & 2.64 & 3.75 & 3.46 & 7.38 & 勢いがある, 激しい, 前が見えない \\
\hline 86 & 学校 - 工場 & 2.64 & 3.62 & 3.38 & 4.83 & 人がたくさんいる, 画一的だ, 生産する \\
\hline 16 & 楽譜 - 暗号 & 2.64 & 3.25 & 5.79 & 7.17 & わからない, 読めない, 難しい \\
\hline 37 & 権力 - 麻薬 & 2.62 & 4.01 & 6.83 & 8.00 & $\begin{array}{l}\text { 一度手に入れると離せない, 中毒性がある, やめら } \\
\text { れない }\end{array}$ \\
\hline 27 & 流星 - 雨粒 & 2.62 & 3.19 & 3.00 & 5.29 & 小さい, 降ってくる, 流れる \\
\hline 10 & 疲労 - 荷物 & 2.62 & 3.12 & 5.79 & 7.33 & 重い, のしかかる, 蓄積していく \\
\hline 53 & うろこ雲 - 羊 & 2.62 & 2.93 & 2.08 & 6.96 & 白い, もこもこしている, ふわふわしている \\
\hline 33 & 沈黙 - 海底 & 2.62 & 2.79 & 2.92 & 7.75 & 暗い, 静かだ, 深い \\
\hline 58 & デモ - 雪崩 & 2.60 & 4.11 & 3.50 & 6.50 & 勢いがある, 止められない, 巻き込む \\
\hline 17 & 希望 - 灯火 & 2.60 & 3.46 & 5.29 & 7.08 & 明るい, 消える, 温かい \\
\hline
\end{tabular}




\begin{tabular}{|c|c|c|c|c|c|c|}
\hline ID & 直喻 & 解釈数 & エントロピー & $\begin{array}{l}\text { 隠喻に対 } \\
\text { する選好 }\end{array}$ & $\begin{array}{l}\text { 喻辞の } \\
\text { 慣習性 }\end{array}$ & 第一, 第二, 第三解釈 \\
\hline 29 & 記憶 - 倉庫 & 2.60 & 3.37 & 5.54 & 4.08 & たくさんある, 整理されている, しまっておける \\
\hline 13 & 恋愛 - 熱病 & 2.60 & 3.35 & 6.08 & 6.50 & 熱くなる, 冷める, 苦しい \\
\hline 99 & 眼 - 湖 & 2.60 & 3.32 & 3.00 & 6.71 & 澄んでいる, 美しい, 反射する \\
\hline 8 & 誘惑 - 蜜 & 2.60 & 2.76 & 5.96 & 8.46 & 甘いもの, 魅力的である, 惹きつける \\
\hline 47 & 老人 - 置物 & 2.60 & 1.98 & 3.38 & 7.38 & 動かない, 静かだ, 存在感がない \\
\hline 12 & 衝撃 - 電気 & 2.58 & 3.71 & 3.25 & 4.46 & 一瞬の出来事だ, 突然来る, ビリビリする \\
\hline 36 & 眉毛 - 毛虫 & 2.58 & 3.57 & 1.79 & 4.79 & 太い, 毛が多い, ゲジゲジしている \\
\hline 73 & 運命 - 通り魔 & 2.58 & 3.41 & 4.46 & 6.04 & 予測できない, 恐ろしい, 突然襲いかかる \\
\hline 45 & 教育 - 階段 & 2.58 & 2.91 & 5.50 & 6.83 & 段階を踏んでいく, 積み重ねる, 一歩ずつだ \\
\hline 1 & 困難 - 壁 & 2.58 & 2.53 & 5.71 & 8.71 & 立ちはだかる, 乗り越えられない, 乗り越えるもの \\
\hline 20 & 不安 - 濃霧 & 2.58 & 2.49 & 2.79 & 8.33 & 先が見えない, 晴れない, 暗い \\
\hline 65 & 眠り-死 & 2.56 & 3.53 & 4.25 & 7.21 & 動かない, 意識がない, 静かだ \\
\hline 28 & 真理 - 迷宮 & 2.54 & 3.37 & 6.50 & 7.75 & たどり着けない, わからない, 探す \\
\hline 59 & 霧 - ベール & 2.52 & 3.36 & 4.29 & 8.33 & 覆う, 前が見えない, 白い \\
\hline 61 & 疑惑 - 腫瘍 & 2.52 & 3.11 & 3.50 & 5.96 & 大きくなる, 膨れ上がる, 厄介だ \\
\hline 81 & 夕日 - 銅貨 & 2.52 & 2.74 & 2.58 & 5.96 & 丸い, 輝いている, 赤い \\
\hline 105 & 建物 - 角砂糖 & 2.52 & 2.69 & 1.79 & 7.00 & 四角い, 脆い, 白い \\
\hline 63 & 時間 - 洪水 & 2.50 & 3.83 & 3.75 & 7.13 & 流れる, 止められない, 逆らえない \\
\hline 25 & 歓喜 - 噴水 & 2.50 & 3.56 & 2.33 & 5.33 & 溢れる, 湧き上がるもの, 湧き出る \\
\hline 88 & 批判 -メス & 2.50 & 3.19 & 4.46 & 7.54 & 鋭い, 人を傷つける, 痛いところをつく \\
\hline 30 & 群衆 - 大河 & 2.50 & 3.16 & 2.79 & 7.54 & 流れる, 多い, 集まる \\
\hline 19 & 心臓 - 時計 & 2.50 & 3.11 & 4.29 & 7.71 & 一定のリズムを刻む, 正確だ, いつか止まる \\
\hline 66 & 教師 - おうむ & 2.50 & 2.38 & 3.42 & 8.17 & $\begin{array}{l}\text { 同じことを何度も言う, 同じことしか言わない, 決 } \\
\text { まったことを言う }\end{array}$ \\
\hline 41 & 犯罪 - 疾病 & 2.48 & 3.95 & 5.46 & 4.33 & 治らない, 誰でもなりうる, 流行りがある \\
\hline 34 & 孤独 - 砂漠 & 2.48 & 3.84 & 5.00 & 5.96 & 寂しい, 辛い, 周りに何もない \\
\hline 104 & 恋 - くす玉 & 2.48 & 3.76 & 4.67 & 4.79 & 楽しい, 弾ける, めでたい \\
\hline 82 & 事典 - 金鉱 & 2.48 & 3.65 & 4.67 & 6.71 & 価值がある, たくさんある, 宝がある \\
\hline 83 & 煙突 - 石碑 & 2.48 & 3.62 & 2.46 & 5.17 & まっすぐ立っている, 堅い, 灰色だ \\
\hline 31 & 時代 - 潮流 & 2.48 & 3.18 & 5.42 & 6.96 & 流れる, 移り変わる, 激しい \\
\hline 89 & 愛 - 季節 & 2.48 & 2.29 & 3.42 & 8.17 & 移り変わる, 繰り返す, 激しい \\
\hline 79 & 梯子 - 背骨 & 2.46 & 3.18 & 3.00 & 5.67 & まっすぐだ, 支える, 硬い \\
\hline 48 & 雨雲 - 薄墨 & 2.46 & 2.96 & 3.42 & 6.58 & 灰色, 暗い, 黒い \\
\hline 42 & 憎悪 - 毒物 & 2.46 & 2.66 & 6.71 & 7.42 & 人を蝕む, 人を苦しめる, 危険だ \\
\hline 64 & 返事 - 山彦 & 2.46 & 2.57 & 3.75 & 7.58 & 返ってくる, 同じことを繰り返す, オウム返しだ \\
\hline 92 & 家族 - 納豆 & 2.44 & 3.43 & 2.58 & 2.33 & 離れられない, 繋がっている, 団結する \\
\hline 84 & 微笑 - さざ波 & 2.42 & 3.32 & 3.13 & 7.04 & 穏やかだ, 静かだ, 優しい \\
\hline 50 & 動悸 - 早鐘 & 2.42 & 3.23 & 3.54 & 5.96 & 速い, 響く, 緊張している \\
\hline 40 & 会話 - 歯車 & 2.42 & 1.64 & 5.38 & 8.13 & 噛み合っている, スムーズだ, 流れがある \\
\hline 98 & 感触 - 火花 & 2.40 & 3.38 & 3.46 & 7.71 & 熱い, 一瞬だ, 痛い \\
\hline 49 & 噂 - 雪だるま & 2.40 & 2.93 & 2.96 & 6.88 & 大きくなる, 膨らむ, 消えてなくなる \\
\hline 90 & 寒波 - 鉄壁 & 2.40 & 2.90 & 4.04 & 5.08 & 冷たい, 逃げられない, 厳しい \\
\hline 11 & 緊張 - 弦 & 2.40 & 1.79 & 2.83 & 7.04 & 張り詰める, 切れる, 緩む \\
\hline 100 & 同情 - 小雨 & 2.38 & 3.44 & 3.46 & 6.13 & 少し, 悲しい, 冷たい \\
\hline
\end{tabular}




\begin{tabular}{|c|c|c|c|c|c|c|}
\hline ID & 直喻 & 解釈数 & エントロピー & $\begin{array}{l}\text { 隠喻に対 } \\
\text { する選好 }\end{array}$ & $\begin{array}{l}\text { 喻辞の } \\
\text { 慣習性 }\end{array}$ & 第一, 第二, 第三解釈 \\
\hline 91 & 皮肉 - 短刀 & 2.38 & 2.31 & 4.54 & 7.21 & 鋭い, 人を傷つける, 心に刺さる \\
\hline 78 & 寝息 - 草笛 & 2.36 & 4.07 & 3.29 & 4.08 & 微かだ, 高い音だ, 心地よい \\
\hline 51 & 呼吸 - ポンプ & 2.34 & 3.30 & 4.83 & 4.13 & 繰り返す, 一定である, 吸って吐く \\
\hline 62 & 微風 - 吐息 & 2.34 & 3.26 & 2.88 & 6.33 & 暖かい, 優しい, 弱い \\
\hline 87 & 日記 - 押し花 & 2.34 & 3.18 & 3.67 & 5.79 & 保存する, 思い出だ, 美しい \\
\hline 56 & 屋根 - 帽子 & 2.34 & 3.08 & 3.50 & 4.67 & 守る, 覆う, おしゃれだ \\
\hline 93 & 景色 - 版画 & 2.34 & 2.96 & 2.50 & 5.54 & 美しい, 鮮やかだ, 目に焼き付ける \\
\hline 69 & 記憶 - 荋 & 2.32 & 3.72 & 3.92 & 3.33 & 大切なもの, 包む, 紡がれる \\
\hline 95 & 礼儀 - 檻 & 2.32 & 3.60 & 4.29 & 5.75 & 堅苦しい, 縛られる, 厳しい \\
\hline 32 & 審判 - 天秤 & 2.32 & 3.24 & 5.21 & 6.58 & 公平である, 平等だ, 判断する \\
\hline 18 & 魅力 - 磁石 & 2.32 & 1.70 & 3.63 & 8.13 & 引きつけられる, 離れられない, 反発する \\
\hline 85 & 利息 - 年貢 & 2.30 & 3.53 & 5.00 & 7.63 & 払わなければならない, 定期的だ, 重い \\
\hline 15 & 寂しさ - 木枯らし & 2.30 & 3.12 & 3.46 & 7.17 & 冷たい, 寒い, 孤独である \\
\hline 75 & 空 - 鏡 & 2.30 & 3.10 & 5.29 & 4.29 & 澄んでいる, 綺麗だ, 映し出す \\
\hline 21 & 治療 - 修理 & 2.30 & 2.78 & 5.50 & 8.33 & 治す, 機械的だ, お金がかかる \\
\hline 97 & 山脈 - 岸辺 & 2.26 & 3.80 & 2.50 & 5.38 & 続く, 連なっている, 雄大だ \\
\hline 80 & 煙草 - 時限爆弾 & 2.26 & 3.26 & 5.88 & 4.17 & 寿命を縮める, 危険だ, 燃える \\
\hline 76 & 月 - お盆 & 2.26 & 2.34 & 2.42 & 6.63 & 丸い, 平に見える, 輝いている \\
\hline 117 & 唇 - 蛭 & 2.24 & 3.83 & 2.67 & 3.08 & 分厚い, 気持ち悪い, 湿っている \\
\hline 112 & 雑巾 - 亀 & 2.24 & 3.46 & 2.13 & 2.54 & 污い, 臭い, 固い \\
\hline 102 & 球場 - バケツ & 2.24 & 2.66 & 2.58 & 1.92 & たくさんの人が入る, 丸い, 広い \\
\hline 67 & 雨傘 - 椎茸 & 2.22 & 3.35 & 2.00 & 1.50 & 似ている, 茶色い, 大きい \\
\hline 46 & 飛び魚 - バッタ & 2.20 & 2.09 & 2.13 & 8.25 & 跳ねる, 高い, 羽がある \\
\hline 106 & 鎖骨 - 横笛 & 2.18 & 3.45 & 2.46 & 4.17 & 細い, 長い, 美しい \\
\hline 114 & 失望 - 樹液 & 2.18 & 3.44 & 2.83 & 7.21 & 甘い, 傷つく, 流れ出る \\
\hline 101 & 汽車 - マッチ箱 & 2.16 & 3.09 & 2.54 & 4.71 & 燃える, 中身が詰まっている, 四角い \\
\hline 43 & 朝顔 - トランペット & 2.12 & 3.81 & 2.83 & 1.71 & 形状が似ている, 明るい, 咲いている \\
\hline 110 & 椿 - ひとだま & 2.12 & 3.18 & 3.29 & 4.00 & 赤い, 丸い, 儚い \\
\hline 103 & 暗闇 - 金属 & 2.12 & 2.44 & 2.96 & 6.96 & 冷たい, 重苦しい, 無機質だ \\
\hline 120 & 霜 - マント & 2.10 & 2.55 & 3.04 & 7.00 & 覆っている, 一面, 薄い \\
\hline 107 & 蛾 - 衛星 & 2.10 & 2.48 & 2.38 & 5.04 & 飛び回る, くるくる回る, 付きまとう \\
\hline 109 & あくび - 満月 & 2.06 & 2.36 & 2.92 & 1.83 & 大きな口を開ける, 丸い, 大きい \\
\hline 115 & 校舎 - 乞食 & 2.06 & 2.35 & 2.92 & 7.42 & みずぼらしい, 污い, 古い \\
\hline 113 & 岬 - 腕 & 2.02 & 2.56 & 2.50 & 5.21 & 長い, 細い, 突き出ている \\
\hline 111 & 休日 - 道しるべ & 1.96 & 3.05 & 4.83 & 2.67 & 休憩するきっかけだ, 目標となる, 必要だ \\
\hline 108 & 電話機 - うさぎ & 1.96 & 2.75 & 2.08 & 7.17 & 白い, 鳴る, 小さい \\
\hline 116 & 美 - 虫歯 & 1.88 & 2.74 & 3.75 & 7.83 & 痛い, 蝕む, 悪だ \\
\hline
\end{tabular}

の種類数を解釈タイプ数とし, 解釈タイプごとに含 まれるトークン数の総和を解釈トークン数とした。 たとえば，「笑顔は花のようだ」という直喻に対して 「美しい」が6トークン, 「明るい」が6トークン,
そして「華やかだ」が4トークン得られた場合, 解 釈タイプ数は 3 であり, 解釈トークン数は 16 とした。 解釈タイプ数と解釈トークン数はエントロピーの算 出の際に用いた。 
Table 2

直喻の特性と解釈産出課題の指標間の相関 $(N=120)$

\begin{tabular}{|c|c|c|c|c|c|c|c|c|c|c|c|}
\hline 指標 & $M$ & $S D$ & 1 & 2 & 3 & 4 & 5 & 6 & 7 & 8 & 9 \\
\hline 1. 理解可能性 ${ }^{\mathrm{a}}$ & 5.42 & 1.42 & - & & & & & & & & \\
\hline 2. 構成語類似性 ${ }^{a}$ & 4.10 & 1.50 & $.92 * * *$ & - & & & & & & & \\
\hline 3. 独創性 a & 4.54 & 0.44 & $-.50 * * *$ & $-.56 * * *$ & - & & & & & & \\
\hline 4. 面白さ a & 4.27 & 0.63 & $.72 * * *$ & $.60 * * *$ & -.06 & - & & & & & \\
\hline $\begin{array}{l}\text { 5. 個人が産出し } \\
\text { た解釈数 }\end{array}$ & 2.49 & 0.23 & $.54 * * *$ & $.52 * * *$ & $-.34 * * *$ & $.46 * * *$ & - & & & & \\
\hline 6. 解釈タイプ数 & 12.90 & 3.33 & .15 & $.15 \dagger$ & -.12 & .08 & $.39 * * *$ & - & & & \\
\hline 7. 解釈トークン数 & 71.34 & 18.45 & $.35 * * *$ & $.33 * * *$ & $-.36 * * *$ & $.30 * *$ & $.59 * * *$ & $.34 * * *$ & - & & \\
\hline 8. エントロピー & 3.15 & 0.53 & .02 & .04 & .02 & -.02 & $.24 * *$ & $.34 * * *$ & .05 & - & \\
\hline 9. 喻辞の慣習性 & 6.33 & 1.69 & $.37 * * *$ & $.41 * * *$ & $-.32 * * *$ & $.25 * *$ & $.40 * * *$ & -.10 & $.30 * *$ & $-.31 * *$ & - \\
\hline $\begin{array}{l}\text { 10. 隠喻に対する } \\
\text { 選好性 }\end{array}$ & 3.85 & 1.36 & $.42 * * *$ & $.46 * * *$ & -.13 & $.33 * * *$ & $.26 * *$ & $.20 *$ & -.13 & $.23 *$ & $.27 * *$ \\
\hline
\end{tabular}

a 中本・楠見 (2004) に基づく。

*** $p<.001, * * p<.01, * p<.05, \uparrow p<.10$

（d）エントロピーはUtsumi（2005）を元に算出し た 3 。先行研究において, エントロピーは直喻のもつ解 釈の多様性を評価するための指標として扱われてきた (Utsumi, 2005, 2007)。先行研究と同様に, 本研究でも エントロピーは解釈の多様性を表す指標として用い た。

以上の手続きを経て，それぞれの直喻に対して個人 が産出した解釈数, 解釈タイプ数, 解釈トークン数, そしてエントロピーを求めた。それぞれの直喻に対す るこれらの解釈指標の值と, それぞれの直喻の解釈 トークン数に基づく, 上位 3 解釈（第一解釈，第二解 釈, 第三解釈), および隠喻の選好性と喻辞の慣習性 の評定平均值を Table 1 にまとめた。直喻は解釈数の 降順で示し，解釈数が同值の場合にはエントロピーの 降順で示した。また，IDは中本・楠見（2004）に準

3 エントロピーは下記の式で表される。

$$
H(X)=-\sum_{i=1}^{n} p\left(x_{i}\right) \log _{2} p\left(x_{i}\right)
$$

本研究において, エントロピーは直喻の（i）解釈タイプ数と（ii) 解釈トークン数に基づいて算出される。たとえば，先に提示し た「笑顔は花のようだ」という直喻に対する回答の例であれば, エントロピーは

$-\left(\frac{6}{16}\right) * \log _{2}\left(\frac{6}{16}\right)-\left(\frac{6}{16}\right) * \log _{2}\left(\frac{6}{16}\right)-\left(\frac{4}{16}\right) * \log _{2}\left(\frac{4}{16}\right)=1.56$

となる。同様に, もし「笑顔は花のようだ」という直喻に対して, 解釈タイプ数が 1 で解釈トークン数が 16 (すなわち, すべての 解釈トークンが同じ解釈タイプ）の場合には，エントロピーは

$-\left(\frac{16}{16}\right) * \log _{2}\left(\frac{16}{16}\right)=0$

となる。このように, エントロピーは表現が多様に分類され， また分類頻度に偏りがないほど值が大きくなる。
じた。

直喻の特性と解釈関連指標間の相関分析 中本・楠 見 (2004) の先行研究で得られた各指標（理解可能性, 構成語類似性, 独創性, 面白さ）と 3 つの課題（解釈 産出課題, 表現の選好性課題, 喻辞の慣習性課題）で 得られた各指標（個人が産出した解釈数, 解釈夕イプ 数, 解釈トークン数, エントロピー, 喻辞の慣習性, 隠喻に対する選好性）間の関係性を明らかにするため に，相関分析を行った（Table 2)。

Table 2 に示すように，構成語類似性は個人が産出 した解釈数と.52の正の相関を示した。このことから, 構成語類似性が高いほど，直喻から産出される解釈が 多くなるという傾向がみられた（予測 1 の支持）。さ らに G*Power (Faul, Erdfelder, Buchner, \& Lang, 2009) を用いて直喻の数 (120 個), 得られた相関係数 (.52), そして $5 \%$ 有意水準をもとに検定力分析を行ったとこ ろ，1.00の検定力が得られた。平他（2006）では 30 個の直喻を用いて, 構成語類似性と個人が産出した解 釈数の相関係数（.38）を報告していたが, 彼らの研 究における検定力は $5 \%$ 有意水準のもとで.68であっ た。これらのことを踏まえると，本研究で用いた直喻 の数で得られた相関係数は, 先行研究と比しても高い 検定力を持っていることを示している。

また, 個人が産出した解釈数は理解可能性（.54） と面白さ（.46）の間に正相関を示し，一方で独創性 (-.34) と負相関を示した。これらの結果は平他 (2006) と同様の相関パターンを示し，理解可能性や面白さが 高いほど直喻から産出される解釈数が多くなるという 傾向と, 独創性が高いほど直喻から産出される解釈数 が少なくなるという傾向がみられた。

一方で，エントロピーは中本・楠見（2004）の各心 
Table 3

隠喻に対する選好性を目的変数とする重回帰分析 $(N=120)$

\begin{tabular}{lccc}
\hline 説明変数 & $B$ & $S E B$ & $\beta$ \\
\hline 構成語類似性 ${ }^{\mathrm{a}}$ & 0.33 & 0.08 & $.36^{* * *}$ \\
エントロピー $^{*}$ & 0.71 & 0.22 & $.28^{* * *}$ \\
喻辞の慣習性 $^{R^{2}}$ & 0.16 & 0.07 & $.20^{* *}$ \\
\hline
\end{tabular}

a 中本・楠見 (2004) に基づく。

$* * * p<.001, * * p<.01$

理言語学的変数と相関は小さかった $(r \mathrm{~s}=.02-.15)$ 。 Utsumi（2007）においてもエントロピーは構成語類似 性と相関は小さかった $(r=.23)$ が，本研究でも同様 の傾向がみられた $(r=.04)$ 。これらの結果と, 構成 語類似性と個人が産出した解釈数掞よび解釈トークン 数との間に正の相関関係がみられた結果 $(r \mathrm{~s}=.52$, .33）を踏まえると, 主題と喻辞が意味的に類似して いることは表現に対する解釈の数が増えることとは関 連しているが, 産出される意味の多様性とは関連して いないことが示唆された。

隠喻に対する選好性の重回帰分析 隠喻に対する選 好性の評定值と，これを予測すると考えられる3つの 変数 (構成語類似性, エントロピー, 喻辞の慣習性) の関係性を明らかにするために重回帰分析を行った (Table 3)。

Table 3 に示すように，喻辞の慣習性が隠喻に対す る選好性を正に予測した（予測 2 の支持）。加えて, エントロピーが隐喻に対する選好性を正に予測した (予測 3 の支持)。さらに, 構成語類似性が隐喻に対す る選好性を正に予測した（予測 4 の支持）。これらの 結果は, 解釈産出課題で集められた第一解釈を用いて 測定される喻辞の慣習性が高く, エントロピーが高く, さらに構成語類似性が高いほど隠喻が選好される傾向 がみられ, 先行研究 (Bowdle \& Gentner, 2005; Chiappe \& Kennedy, 2001; Utsumi, 2007）の予測を支持した。

\section{まと め}

本研究の目的は, 比喻とその解釈を収集し, 比喻研 究のための刺激セットを作成することであった。そし て, 本研究で得られた刺激セットが妥当であるかを検 討するために，中本・楠見（2004）で収集された心理 的変数と, 本研究で新たに収集した心理的変数を用い て, 先行研究の知見や理論から立てられた仮説に対す る4つの予測を支持するかを検討した。本研究の結果, 構成語類似性と個人が産出した解釈数は正の相関を示 した（予測 1 の支持）。さらに，重回帰分析において 喻辞の慣習性, エントロピー, そして構成語類似性が 隠喻に対する選好性を正に予測した（予測 2，3，4の 支持)。これらの結果は, 先行研究で得られた結果 (Katz et al., 1988; 平他, 2006) や理論（Bowdle \& Gentner, 2005; Chiappe \& Kennedy, 2001; Utsumi, 2007）から予 測される結果を, 先行研究よりも十分に多い直喻表現 を対象に再現し, 本研究で得られた刺激一解釈セット の妥当性を確認した。

本研究で得られた直喻の解釈は, 本研究で行った隠 喻に対する選好性との関連を明らかにする研究だけで なく, 直喻の理解に関わる様々な研究で使用できると 考えられる。たとえば比喻の理解研究としては, 直喻 から喚起される複数の解釈を順に提示することで比喻 の面白さがどのように変化するか（平他，2012）を明 らかにする際に, 本研究で得られた回答頻度の高い解 釈は有用であろう。また比喻の産出研究としては, 主 題と, 関連のある解釈を特徵として提示して比喻表現 を産出させる課題 (Beaty \& Silvia, 2013; Chiappe \& Chiappe, 2007; Utsumi \& Sakamoto, 2014）を行う際に, 本研究で報告される回答頻度の高い解釈を特徵として 用いることで, 研究者の関心に合わせて柔軟に特徴を 選ぶことができるだろう。ただし，本研究で得られた 解釈は, 比喻を文章などの文脈から切り離した状況で 得られたものである点は留意する必要がある。今後は, 文章などの文脈が与えられた状況での, 比喻の解釈に ついても明らかにする必要がある。

本研究で得られた解釈は比喻の理解・産出に関わる 計算言語学的研究に対しても有益であると考える。た とえば Kintsch (2000) は, 主題と喻辞を入力とするこ とで，その解釈ベクトルをコサイン類似度の高い順に 出力する計算モデルである, Predication モデルを提案 している。また, Kintsch \& Bowles (2002) は Predication モデルによって計算される解釈を定量的に評価するた めに, 人が比喻表現に対して産出した解釈との類似性 を評価し，モデルと人の比喻の解釈が十分に類似して いたことを報告している。このように，比喻の解釈の 計算モデルの妥当性は, 計算モデルが出力した解釈と, 人の比喻の解釈の類似性に基づいて評価される (Kintsch \& Bowles, 2002; Shutova, Teufel, \& Korhonen, 2013)。こう した研究に対して, 本研究で得られた回答頻度の高い 解釈が提案されたモデルの解釈ベクトルの中で何番目 に出てくるか (例: 平均逆順位) を評価することによっ て, 比喻の解釈の計算モデルの妥当性をより適切に評 価できるようになると考えられる。

\section{利益相反}

本研究で報告すべき利益相反関連事項はない。

\section{引用文献}

Beaty, R. E., \& Silvia, P. J. (2013). Metaphorically speaking: Cognitive abilities and the production of figurative language. Memory \& Cognition, 41, 255-267. 
Bowdle, B. F., \& Gentner, D. (2005). The career of metaphor. Psychological Review, 112, 193-216.

Chiappe, D. L., \& Chiappe, P. (2007). The role of working memory in metaphor production and comprehension. Journal of Memory and Language, 56, 172-188.

Chiappe, D. L., \& Kennedy, J. M. (2001). Literal bases for metaphor and simile. Metaphor and Symbol, 16, 249276.

Faul, F., Erdfelder, E., Buchner, A., \& Lang, A. G. (2009). Statistical power analyses using $\mathrm{G}^{*}$ Power 3.1: Tests for correlation and regression analyses. Behavior Research Methods, 41, 1149-1160.

榛谷 泰明 (1994)。レトリカ一比喻表現辞典— 白水社

Katz, A. N., Paivio, A., Marschark, M., \& Clark, J. M. (1988). Norms for 204 literary and 260 nonliterary metaphors on 10 psychological dimensions. Metaphor and Symbolic Activity, 3, 191-214.

Kintsch, W. (2000). Metaphor comprehension: A computational theory. Psychonomic Bulletin \& Review, 7, 257-266.

Kintsch, W., \& Bowles, A. R. (2002). Metaphor comprehension: What makes a metaphor difficult to understand? Metaphor and Symbol, 17, 249-262.

楠見 孝 (1995). 比喻の処理過程と意味構造 風間書 房

Nakamoto, K. (2003). Semantic priming effect of metaphor constituent terms. Perceptual and Motor Skills, 96, $33-42$.

中本敬子・楠見 孝 (2004). 比喻材料文の心理的特性 と分類——基準表作成の試み——読書科学, 48, $1-10$.
中村明 (1994)。比喻表現辞典 角川書店

Ortony, A., Vondruska, R. J., Foss, M. A., \& Jones, L. E. (1985). Salience, similes and the asymmetry of similarity. Journal of Memory and Language, 24, 569594.

Shutova, E., Teufel, S., \& Korhonen, A. (2013). Statistical metaphor processing. Computational Linguistics, 39 , $301-353$.

平知宏・楠見孝 (2005). 比喻の親しみやすさによる 意味解釈の差異 日本心理学会第 69 回大会発表 論文集，941.

平 知宏 - 楠見 孝 - 内海 彰 (2012). 比喻理解と解釈, 作動記憶の関係 日本認知科学会第 29 回大会発 表論文集，485-489.

平知宏・中本敬子 - 楠見 孝 (2006). 直喻文の理解 容易性と解釈多様性が面白さに及ぼす効果——理 解がしやすく多くの解釈ができるから面白い一 日本心理学会第 70 回大会発表論文集, 240 .

平知宏・中本敬子・楠見孝 (2007). 比喻理解にお ける親しみやすさと解釈の多様性 認知科学, 14, 322-338.

Utsumi, A. (2005). The role of feature emergence in metaphor appreciation. Metaphor and Symbol, 20, 151172.

Utsumi, A. (2007). Interpretive diversity explains metaphor-simile distinction. Metaphor and Symbol, 22, $291-312$.

Utsumi, A., \& Sakamoto, M. (2014). Discourse goals affect the process and product of nominal metaphor production. Journal of Psycholinguistic Research, 43, 1-17.

- 2018.2.16 受稿, 2018. 7.7 受理—— 